\section{Erythrozyten, polychromatische}

H. Baum

Institut für Laboratoriumsmedizin, Mikrobiologie und Blutdepot, Regionale Kliniken Holding RKH GmbH, Ludwigsburg, Deutschland

Synonym(e) Polychromasie

Englischer Begriff polychromatic erythrocyte

Definition In der panoptischen Färbung nach Pappenheim ( $\triangleright$ Pappenheim-Färbung) bläulich (basophil) gefärbte Erythrozyten.

Beschreibung Im Ausstrichpräparat sind Erythrozyten nachweisbar, bei denen die Kern- und Zytoplasmareifung nicht parallel abgelaufen sind. Obwohl der Kern bereits ausgestoßen ist, enthält das Zytoplasma noch RNA, die sich mit basischen Farbstoffen bläulich anfärbt. Der Nachweis polychromatischer Erythrozyten (s. Abbildung) ist ein Zeichen einer erhöhten Regenerationsaktivität des Knochenmarks und kann häufig bei Anämien beobachtet werden. Sie entsprechen somit den Retikulozyten.
Neben oxyphilen Erythrozyten sind in der Abbildung bläulich gefärbte (polychromatische) Erythrozyten nachweisbar $(1000 \times$, May-Grünwald-Giemsa-Färbung):

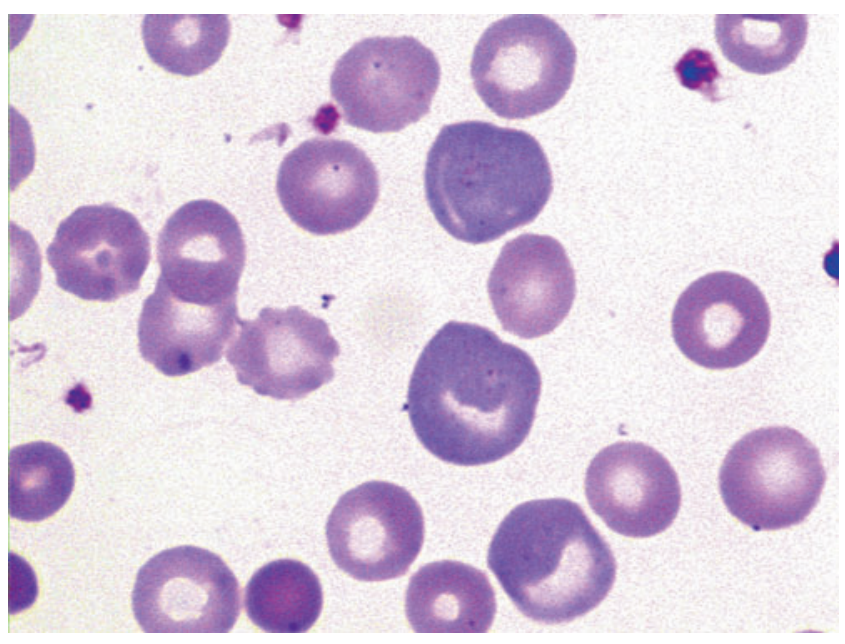

\section{Literatur}

Bain BJ (2001) Blood cell morphology in health and disease. In: Lewis SM, Bain BJ, Bates I (Hrsg) Practical haematology, 9. Aufl. Churchill Livingstone, London, S 86 